\title{
Novel neuroprotective peptides in the venom of the solitary scoliid wasp Scolia decorata ventralis
}

\author{
Carlos Alberto-Silva ${ }^{1 *}$ (D), Fernanda Calheta Vieira Portaro² ${ }^{\mathbb{D}}$, Roberto Tadashi Kodama², Halyne Queiroz \\ Pantaleão ${ }^{1}$, Marisa Rangel ${ }^{2}$, Ken-ichi Nihei ${ }^{3}$, Katsuhiro Konno ${ }^{4 *}$ (D) \\ ${ }^{1}$ Natural and Humanities Sciences Center, Experimental Morphophysiology Laboratory, Federal University of ABC (UFABC), São Bernardo do Campo, \\ SP, Brazil. \\ ${ }^{2}$ Immunochemistry Laboratory, Butantan Institute, São Paulo, SP, Brazil. \\ ${ }^{3}$ Faculty of Agriculture, Utsunomiya University, Utsunomiya, Tochigi, Japan. \\ ${ }^{4}$ Institute of Natural Medicine, University of Toyama, Toyama, Toyama, Japan.
}

\section{Keywords:}

Comprehensive analysis

LC-ESI-MS

Solitary wasp

Venom

Neuroprotective peptide

\begin{abstract}
Background: Solitary wasp venoms may be a rich source of neuroactive substances, since their venoms are used for paralyzing preys. We have been exploring bioactive constituents of solitary wasp venoms and, in this study, the component profile of the venom from a solitary scoliid wasp, Scolia decorata ventralis, was investigated through a comprehensive analysis using LC-MS. Two peptides were synthesized, and their neuroprotective properties were evaluated.

Methods: A reverse-phase HPLC connected to ESI-MS was used for LC-MS analyses. Online mass fingerprinting was performed from TIC, and data-dependent tandem mass spectrometry gave the MS/MS spectra. The sequences of two major peptide components were determined by MALDI-TOF/TOF MS analysis, confirmed by solid phase synthesis. Using the synthetic peptides, biological activities were assessed. Cell integrity tests and neuroprotection analyzes using $\mathrm{H}_{2} \mathrm{O}_{2}$ as an oxidative stress inducer were performed for both peptides.

Results: Online mass fingerprinting revealed that the venom contains 123 components, and the MS/MS analysis resulted in 33 full sequences of peptide components. The two main peptides, $\alpha$-scoliidine (DYVTVKGFSPLR) and $\beta$-scoliidine (DYVTVKGFSPLRKA), present homology with the bradykinin C-terminal. Despite this, both peptides did not behave as substrates or inhibitors of ACE, indicating that they do not interact with this metallopeptidase. In further studies, $\beta$-scoliidine, but not $\alpha$-scoliidine, showed protective effects against oxidative stress-induced neurotoxicity in PC12 cells through integrity and metabolism cell assays. Interestingly, $\beta$-scoliidine has the extension of the KA dipeptide at the C-terminal in comparison with $\alpha$-scoliidine.

Conclusion: Comprehensive LC-MS and MS/MS analyses from the Scolia decorata ventralis venom displayed the component profile of this venom. $\beta$-scoliidine showed an effective cytoprotective effect, probably due to the observed increase in the number of cells. This is the first report of solitary wasp venom peptides showing neuroprotective activity.
\end{abstract}

\footnotetext{
* Correspondence: carlos.asilva@ufabc.edu.br and kkgon@inm.u-toyama.ac.jp https://doi.org/10.1590/1678-9199-JVATITD-2020-0171

Received: 19 November 2020; Accepted: 01 March 2021; Published online: 11 June 2021
} 


\section{Background}

Arthropod venoms are a rich source of bioactive and potentially useful peptides [1]. In particular, spider and scorpion venoms have a variety of neuroactive peptides acting on ion channels and receptors. They have been used for studying neuronal functions and some of them may be useful for medical and agricultural application [2,3]. It is the case for Hymenopteran insect venoms from social bees and wasps such as honeybees and hornets. Their venoms are used for defending their nests, larvae and themselves from predators and are composed of a variety of peptides and proteins [4].

We are interested in solitary wasps and have researched their venom components over the past few decades. Solitary wasps use their venoms to capture and paralyze their prey, insects and spiders, and feed their larvae with paralyzed prey [5]. Accordingly, solitary wasp venoms may have neuroactive substances as major components. In fact, we found sodiumchannel blocking neurotoxins, $\alpha$ - and $\beta$-pompilidotoxins, in spider wasp venoms [6,7], and ASIC channel inhibitor, Sa12b, in sphecid wasp venoms [8]. Additionally, bradykinin-related peptides [9] and antimicrobial peptides [10] were also found. Thus, our studies of solitary wasp venom components revealed that the venoms contain not only neuroactive peptides but also a variety of bioactive peptides [11].

The first study of solitary wasp venoms was reported in 1987. Two kinins, threonine ${ }^{6}$-bradykinin $\left(\mathrm{Thr}^{6}-\mathrm{BK}\right)$ and megascoliakinin, were isolated and characterized from the venoms of the European scoliid wasps Colpa interrupta and Megascolia flavifrons, respectively $[12,13]$. These kinins irreversibly block the synaptic transmission of the nicotinic acetylcholine receptor ( $\mathrm{nAChR}$ ) in the prey central nervous system $[13,14]$. Thr ${ }^{6}-\mathrm{BK}$ may be a common component of solitary scoliid wasp venoms, since we identified this peptide as a major component in three scoliid wasp venoms found in Japan [15]. $\mathrm{Thr}^{6}-\mathrm{BK}$ is also present in the venom of the spider wasp Cyphononyx dorsalis (Cyphononyx fulvognathus), which contains three other bradykinin-related peptides: cyphokinin, fulvonin and Cd-146 [9].

In this study, we focused on another Japanese species of solitary scoliid wasp, Scolia decorata ventralis, belonging to Scoliidae family and Scolia genus, and preying beetle larva in the ground. Comprehensive LC-MS and MS/MS analyses of the crude venom extract depicted the component profile of this venom, and the two major peptide components, $\alpha$-scoliidine and $\beta$-scoliidine, were bradykinin-related peptides. In neuroprotective assays, $\beta$-scoliidine showed an effective cytoprotective effect, probably due to the observed increase in the number of cells. This is the first report on solitary wasp venom peptides showing neuroprotective activity.

\section{Methods}

\section{Materials}

All chemicals used in the present study were of analytical reagent grade (purity higher than 95\%) and purchased from Calbiochem-Novabiochem Corporation (USA), Gibco BRL (New York, USA), Fluka Chemical Corp. (Buchs, Switzerland) or Sigma-Aldrich Corporation (MO, USA). The ACE I from rabbit lung (EC 3.4.15.1) from Sigma-Aldrich. For the reverse phase chromatography, acetonitrile and TFA were acquired from J.T. Baker. The FRET substrate Abz-FRK(Dnp)P-OH (used by ACE-I assays) were provided by Prof. Adriana Carmona, from the Department of Biophysics of UNIFESP-EPM, São Paulo, Brazil.

\section{Wasp collection}

Five female wasp individuals of Scolia decorata ventralis were collected manually by an insect-catching net in Kyoto, Japan, in August 2010. The venom sacs were dissected under a low temperature anesthetization and extracted with 50\% $\mathrm{MeCN}$ (acetonitrile) /water. The extracts were lyophilized and stored at $-35{ }^{\circ} \mathrm{C}$ until use.

\section{LC-ESI-MS}

The crude venom was analyzed with a LC (Accela 600 Pump, Thermo Scientific) connected with ESI-FTMS (LTQ Orbitrap $\mathrm{XL}$, Thermo Scientific). The lyophilized venom sac extracts were dissolved into $500 \mu \mathrm{L}$ of water, and from this solution, $10 \mu \mathrm{L}$ (corresponding to $10 \%$ amount of crude venom sac extracts from a single specimen) was subjected to reversed-phase HPLC using CAPCELL PAK C ${ }_{18}$ UG 120, 1.5 x 150 mm (SHISEIDO Co., Ltd., Tokyo, Japan) with linear gradient from $5 \%$ to $65 \%$ $\mathrm{CH}_{3} \mathrm{CN} / \mathrm{H}_{2} \mathrm{O} / 0.1 \%$ (v/v) formic acid at a flow rate of $200 \mu \mathrm{L} / \mathrm{min}$ over $20 \mathrm{~min}$ at $25{ }^{\circ} \mathrm{C}$. ESI-FTMS was operated by Xcalibur ${ }^{\mathrm{TM}}$ software (Thermo Scientific) as: capillary voltage, $+4.6 \mathrm{kV}$; capillary temp., $350{ }^{\circ} \mathrm{C}$; sheath and aux gas flow, 50 and 30 , respectively (arbitrary units); resolution, $5 \mathrm{ppm}$. MS/MS spectra were obtained by data dependent MS/MS mode (two most intense peaks by HCD) and the obtained spectra were manually analyzed to give peptide sequences, which were confirmed by MS-Product in ProteinProspector program (http://prospector. ucsf.edu/prospector/cgi-bin/msform.cgi?form $=$ msproduct).

\section{MALDI-TOF MS}

MALDI-TOF MS spectra were acquired on an Autoflex TOF/ TOF mass spectrometer (Bruker Daltonics, Yokohama, Japan) equipped with $337 \mathrm{~nm}$ pulsed nitrogen laser under reflector mode. The resolution and accuracy of MS were 18000 full width at half maximum $(\mathrm{m} / \mathrm{z} 3000)$ and $10 \mathrm{ppm}$, respectively. The accelerating 
voltage was $20 \mathrm{kV}$. Matrix, $\alpha$-cyano-4-hydroxycinnamic acid (Aldrich), was prepared at a concentration of $10 \mathrm{mg} / \mathrm{mL}$ in $1: 1$ $\mathrm{CH}_{3} \mathrm{CN} / 0.1 \%(\mathrm{v} / \mathrm{v})$ TFA. External calibration was performed with [Ile $\left.{ }^{7}\right]$-angiotensin III $(m / z$ 897.51, monoisotopic, Sigma) and human ACTH fragment $18-39(\mathrm{~m} / z 2465.19$, monoisotopic, Sigma). The sample solution $(0.5 \mu \mathrm{L})$ dropped onto the MALDI sample plate was added to the matrix solution $(0.5 \mu \mathrm{L})$ and allowed to dry at room temperature. For TOF/TOF measurement, argon was used as a collision gas and ions were accelerated at $19 \mathrm{kV}$. The series of $b$ and $y$ ions were afforded, which enabled identification of whole amino acid sequence by manual analysis.

\section{Peptide synthesis}

The peptides were synthesized using Fmoc chemistry by GenScript (Nanjing, Jiangsu, China). The crude products were purified by RP-HPLC with a preparative C18 column, and the purity and molecular weight of the final peptides were verified by HPLC and MS.

\section{Kinetic analyses with $\alpha$-scoliidine and $\beta$-scoliidine as NEP and ACE inhibition}

Experiments were performed using different concentrations of both peptides with ACE and the Abz-FRK(Dnp)P-OH as substrate. The assays used $7.5 \mathrm{ng}$ of the peptidase and the substrate was added in a $100 \mathrm{mM}$ Tris- $\mathrm{HCl}$ buffer containing 50 $\mathrm{mM} \mathrm{NaCl}, 10 \mu \mathrm{M} \mathrm{ZnCl}_{2}, \mathrm{pH} 7.0$ (final volume of $100 \mu \mathrm{L}$ ). Three FRET substrate concentrations were used $(2 \mu \mathrm{M}, 4 \mu \mathrm{M}$ and $8 \mu \mathrm{M})$, and were incubated with three concentrations of both peptides $(20 \mu \mathrm{M}, 30 \mu \mathrm{M}$ and $50 \mu \mathrm{M})$. Controls without the peptides were also performed in all assays. The reaction was monitored during 15 minutes on fluorimeter (Victor 3 - Perkin-Elmer) and the results were analyzed on GraFit 3.0 from Erithacus Software. All assays were performed in triplicate.

\section{$\alpha$-scoliidine and $\beta$-scoliidine stability tests}

Both peptides $(30 \mu \mathrm{M})$ were incubated separately with ACE $(7.5 \mathrm{n})$ at $37^{\circ} \mathrm{C}$ for four hours. Samples containing only the synthetic peptides were used as negative control. After incubation, samples were analyzed by reverse phase chromatography on HPLC (Prominence, Shimadzu), using a Shim-pack VP-ODS C-18 column $(4.6 \times 150 \mathrm{~mm})$. Solvents used were $0.1 \%(\mathrm{v} / \mathrm{v}) \mathrm{TFA}$ in water (solvent A), and acetonitrile plus solvent A (9:1) as solvent B. Separations were performed at a flow rate of $1 \mathrm{~mL} / \mathrm{min}$ and a $10-60 \%$ gradient of solvent B over $20 \mathrm{~min}$. In all cases, elution was followed by the measurement of ultraviolet absorption $(214 \mathrm{~nm})$.

\section{PC12 cell culture}

Neuronal cell line (PC12) was used to evaluate the neuroprotective effects of $\alpha$-scoliidine and $\beta$-scoliidine against oxidative stress in vitro. PC12 cell is derived from a transplantable rat pheochromocytoma and was purchased from American Type Culture Collection (USA) (ATCC ${ }^{\circledR}$ CRL-1721 $^{\mathrm{m}}$ ). Cells were routinely cultured in DMEM medium (Sigma-Aldrich) supplemented with $10 \%$ fetal bovine serum (Gibco, Waltham, USA), $1 \%$ (v/v) of $10000 \mathrm{U} / \mathrm{mL}$ penicillin, $10 \mathrm{mg} / \mathrm{mL}$ streptomycin and $25 \mu \mathrm{g} / \mathrm{mL}$ amphotericin B solution (Sigma-Aldrich) at $37^{\circ} \mathrm{C}$ in an atmosphere of $5 \% \mathrm{CO}_{2}$ and $95 \%$ air (Water Jacketed $\mathrm{CO}_{2}$ Incubator, Thermo Scientific). At $80 \%$ confluence, cells were passaged using trypsin-EDTA solution $[0.05 \%(\mathrm{~m} / \mathrm{v})$ trypsin and $0.02 \%(\mathrm{~m} / \mathrm{v})$ EDTA]. Culture medium was replaced every 2-3 days.

\section{Cell toxicity studies}

PC12 cells were seeded into 96-well plates (Nest Biotechnology, Rahway, USA), at $2.0 \times 10^{4}$ cells per well, and were treated with different concentrations $(0.1$ to $10 \mu \mathrm{M})$ of $\alpha$-scoliidine and $\beta$-scoliidine in a final volume of $0.15 \mathrm{~mL}$. The plate was incubated at $37^{\circ} \mathrm{C}$ for $3,6,12,24$, and $48 \mathrm{~h}$. For each concentration and time course studied, there were control and DMSO groups, which represent untreated cells (only one equal volumes of the culture medium) and treated with DMSO 2.5\% (v/v) diluted in the medium culture, respectively. The cytotoxic effects of both compounds were determined using crystal violet assay, according to Feoktistova et al. [16]. Briefly, the medium was aspirated, and the cells were washed twice in a gentle stream of tap water. Then, $50 \mu \mathrm{L}$ of a $0.5 \%$ (v/v) crystal violet staining solution was added to each well, and incubated for $20 \mathrm{~min}$ at room temperature on a bench rocker with a frequency of 20 oscillations per min. The plate was washed four times and air-dried for at least $2 \mathrm{~h}$ at room temperature. Subsequently, methanol $(200 \mu \mathrm{L})$ was added to each well, and the plate was incubated with its lid on for 20 min at room temperature on a bench rocker with a frequency of 20 oscillations per min. After, the absorbance of the sample was measured at $570 \mathrm{~nm}$ using a SpectraMax reader (Molecular Devices, CA, USA). The cytotoxicity was expressed as percentage (\%) of cell integrity relative to control cells (100\%).

\section{Neuroprotective assay}

PC12 cells were seeded at $2 \times 10^{4}$ cells/well in a 96-well plate (Nest Biotechnology, Rahway, USA) for $24 \mathrm{~h}$, and then two neuroprotective assays were evaluated: 1 ) Cells were pre-treated with $\alpha$-scoliidine or $\beta$-scoliidine $(1 \mu \mathrm{M})$ at $37^{\circ} \mathrm{C}$ for $22 \mathrm{~h}$ and, after the mediums were replaced containing the peptide and $\mathrm{H}_{2} \mathrm{O}_{2}$ $(0.6 \mathrm{mM})$ and incubated for $2 \mathrm{~h}$ more; 2$)$ Cells were pre-treated with $\alpha$-scoliidine or $\beta$-scoliidine $(1 \mu \mathrm{M})$ for $4 \mathrm{~h}$ at $37^{\circ} \mathrm{C}$ and, after the mediums were replaced containing peptide and $\mathrm{H}_{2} \mathrm{O}_{2}(0.6$ $\mathrm{mM}$ ) and incubated for $20 \mathrm{~h}$ more. The control, $\alpha$-scoliidine and $\beta$-scoliidine groups (without $\mathrm{H}_{2} \mathrm{O}_{2}$ ) were incubated under the same conditions. Next, all experimental groups were analyzed by the crystal violet assay.

\section{Mitochondrial metabolism evaluation}

The effects of $\alpha$-scoliidine or $\beta$-scoliidine on the mitochondrial metabolism of PC12 cells were estimated using 3-(4,5-dimethylthiazol-2-yl)-2,5-diphenyltetrazolium bromide (MTT) reduction assay, as previously described $[17,18]$. 
Briefly, cells were placed on 96-well plates (Nest Biotechnology, Rahway, USA) at $2.0 \times 10^{4} /$ well, and treated as described above for neuroprotection assays - protocol 2 . In addition, to the experimental groups mentioned above, two more groups were included in which cells were treated with $\mathrm{L}-\mathrm{N}^{\Omega}$-Nitroarginine methyl ester (L-Name; $1 \mathrm{mM}$ ) and Bradykinin (Bk; $0.3 \mu \mathrm{M})$ in the presence or absence of $\mathrm{H}_{2} \mathrm{O}_{2}$. After treatments, cells were treated with $0.5 \mathrm{mg} / \mathrm{mL}$ MTT in the same medium culture for $3 \mathrm{~h}$ at $37^{\circ} \mathrm{C}$. The resulting formazan produced by both cell treatments were dissolved by addition of DMSO. The amount of MTT formazan dissolved in DMSO was determined by measuring absorbance with a microplate reader (Spectramax M3 multi-mode, Molecular Devices, CA, EUA) at $540 \mathrm{~nm}$. Data were expressed as the mean \pm SD of mitochondrial metabolism percentage in relation to the control.

\section{Statistical analyses}

All data are presented as mean \pm SD of three independent experiments $(n=3)$ in triplicate. Data were analyzed using one-way analysis of variance (ANOVA) for between-groups comparisons followed by a Tukey's post-hoc test for multiple comparisons. Values of $p<0.05$ were considered to be statistically significant. The analyses were performed using GraphPad Prism 6.0 software (GraphPad Software, Inc., La Jolla, CA).

\section{Results}

\section{Online mass fingerprinting by LC-MS}

The crude venom extract was first subjected to LC-ESI-MS in order to verify the component profile: number of components and its molecular mass determination. The TIC profile is shown in Figure 1. The volume of the sample solution never exceeded the amount of $10 \%$ of crude venom, being a single specimen

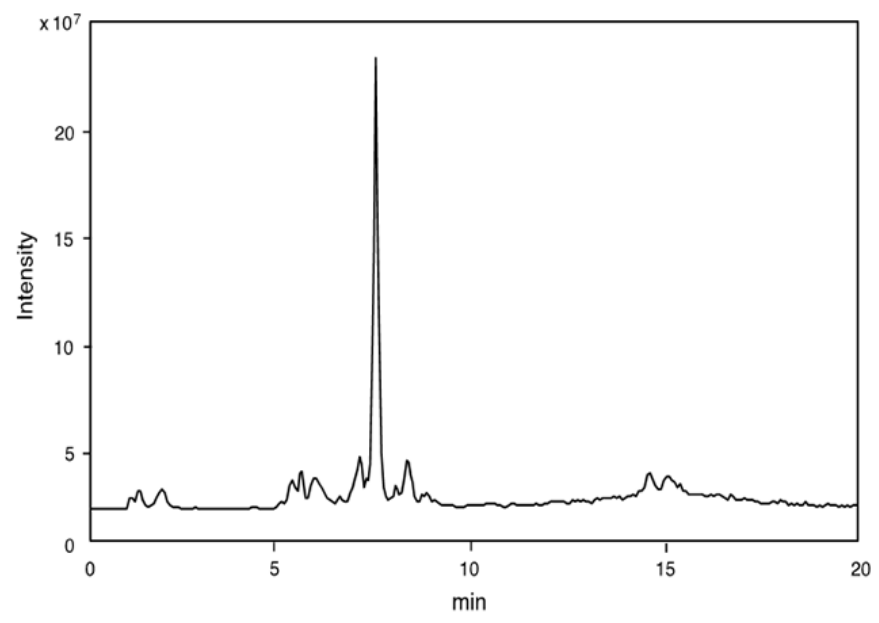

Figure 1. TIC profile from LC-ESI-MS of crude venom extracts of Scolia decorata ventralis. An amount of $10 \%$ of crude venom extracts of a single specimen was applied to reverse-phase HPLC using CAPCELL PAK C18 $(1.5 \times 150 \mathrm{~mm})$ with linear gradient of $5-65 \% \mathrm{CH} 3 \mathrm{CN} / \mathrm{H} 2 \mathrm{O} / 0.1 \%(\mathrm{v} / \mathrm{v})$ formic acid over $20 \mathrm{~min}$ at flow rate of $200 \mu \mathrm{L} / \mathrm{min}$. sufficient for LC-ESI-MS analysis (mass fingerprinting and peptide sequencing). Online mass fingerprint was prepared from TIC by "virtual fractionation", collecting MS spectra from certain range of retention time (fractions), and then, the molecular mass was analyzed in each fraction. The results are summarized in Table 1. The TIC profile seems to be simple, but comprehensive analysis resulted to find a large number of components in this venom extract. A total of 123 molecular mass in $\mathrm{m} / \mathrm{z}$ range of 90-9500 were obtained from 17 virtual fractions. The low molecular mass components $(33$ components, $\mathrm{m} / z$ 90-300) may be free amino acids, biogenic amines and nucleic acids, and those of $\mathrm{m} / z$ range $300-9500$ should be peptides (91 components), in particular, those of $m / z 500-2000$ (68 components) accounts for $75 \%$ of the peptide components, implying that major components in this venom are relatively small peptides.

\section{Identification of small molecules (amino acids, biogenic amines and nucleic acids)}

A total of 33 small molecules (17 amino acids, 7 biogenic amines, 9 nucleic acids) were identified as summarize in Tables 2-4. The identification was made by the previously reported method [19]: elemental composition analysis of molecular ion $(\mathrm{M}+\mathrm{H})^{+}$with error limit of $0.005 \mathrm{Da}$, and in some cases, concomitant detection of iminium ion and deamination $\left(-\mathrm{NH}_{3}\right)$ peak. For nucleic acids (AMP, ADP and NAD), MS/MS spectra were obtained by data dependent MS/MS measurement, which confirmed the structure of these compounds. Usually, analysis of these small molecules by reverse-phase HPLC is not easy because they are eluted as a complex mixture in the solvent front portion. Accordingly, derivatization or special HPLC conditions are needed to analyze [20-22]. In contrast, the method utilizing LC-MS, as previously reported and shown here, is easy and advantageous that it can be applicable for small molecule analysis of any animal venom.

\section{Peptide sequencing by LC-MS/MS analysis}

Data dependent MS/MS measurement with LC-MS afforded MS/MS spectra from 60 peptide molecules. Manual sequence analysis of these MS/MS spectra revealed the full sequence of 33 peptides, and the rest of the 27 peptides were only partially sequenced (data not shown). The analyzed full sequences are shown in Table 5.

The two most intense peaks in Fr. 9 and 11 contained the major peptides $\beta$-scoliidine ( $m / z$ 1580.880, DYVTVKGFSPLRKA) and $\alpha$-scoliidine ( $m / z$ 1381.748, DYVTVKGFSPLR), respectively. They are different each other only at the $\mathrm{C}$-terminal: $\beta$-scoliidine has the dipeptide KA at the C-terminal of $\beta$-scoliidine. L (leucine) at the position 11 of both peptides was determined by MALDI TOF/TOF analysis. The MALDI TOF/TOF spectra of both peptides showed $W a$ ion peak: $\beta$-scoliidine, $m / z 482.2\left(W_{a 4}\right)$; $\alpha$-scoliidine $m / z 229.0\left(W_{a 2}\right)$, which clearly showed that the residue at these positions are both $\mathrm{L}$ (leucine), not I (isoleucine). The solid-phase synthesis of these peptides, and the HPLC and 
Table 1. Online mass fingerprinting of crude venom extract from Scolia decorata ventralis by LC-ESI-MS.

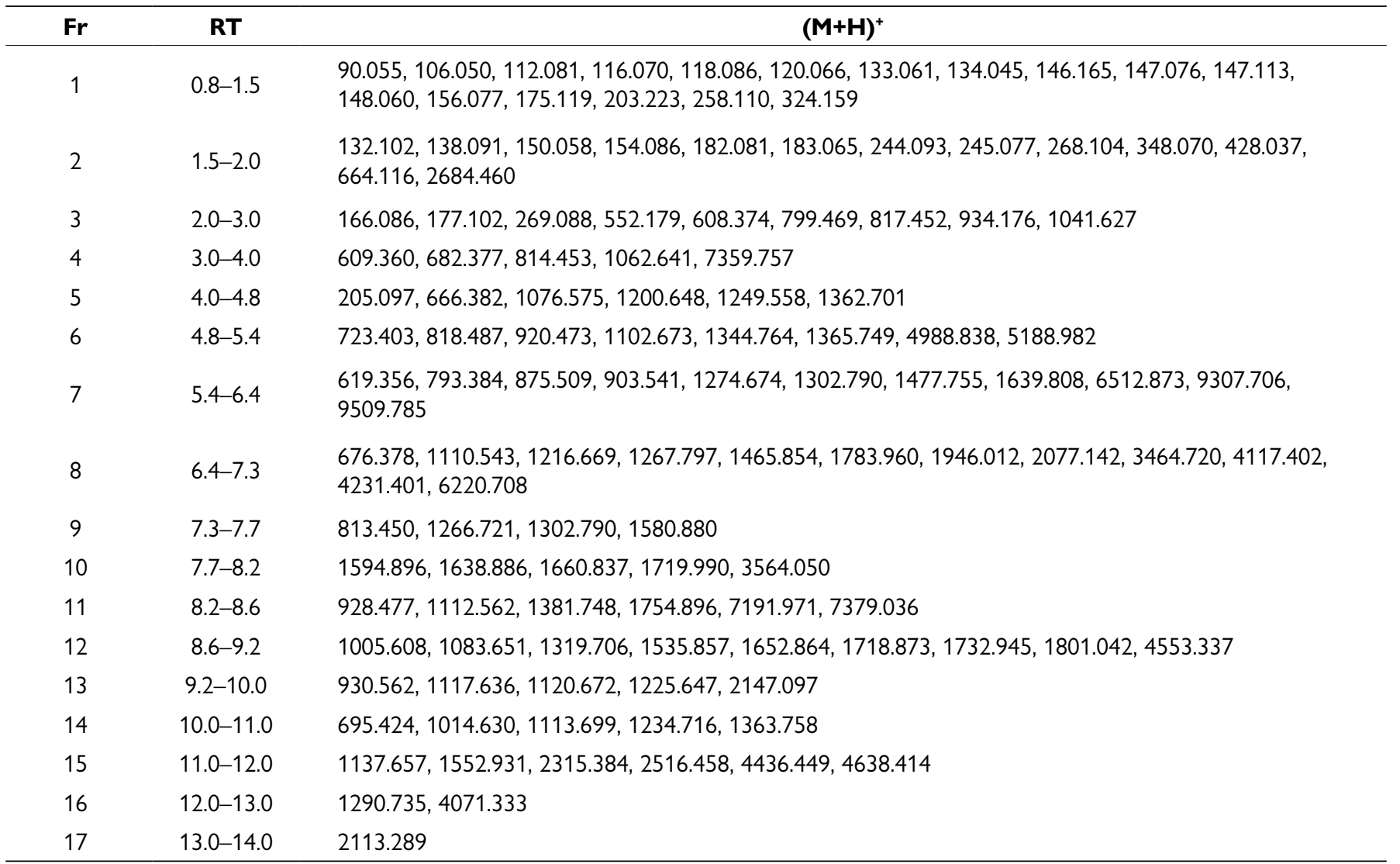

Table 2. Amino acids in the crude venom extract from Scolia decorata ventralis by LC-ESI-MS.

\begin{tabular}{|c|c|c|c|c|c|c|}
\hline $\begin{array}{c}\text { RT } \\
(\mathrm{min})\end{array}$ & $\begin{array}{l}\text { Intensity } \\
\times 10^{4}\end{array}$ & $\begin{array}{c}{[M+H]^{+}} \\
m / z\end{array}$ & $\begin{array}{l}\text { Elemental } \\
\text { composition }\end{array}$ & $\begin{array}{c}\text { Iminium ion } \\
\mathrm{m} / \mathrm{z}\end{array}$ & $\begin{array}{l}\text { Elemental } \\
\text { composition }\end{array}$ & Compound \\
\hline 1.11 & 6 & 147.113 & $\mathrm{C}_{6} \mathrm{H}_{15} \mathrm{~N}_{2} \mathrm{O}_{2}$ & - & & Lysine \\
\hline \multirow{5}{*}{1.25} & 2 & 106.050 & $\mathrm{C}_{3} \mathrm{H}_{8} \mathrm{NO}_{3}$ & - & & Serine \\
\hline & 8 & 120.065 & $\mathrm{C}_{4} \mathrm{H}_{10} \mathrm{NO}_{3}$ & - & & Threonine \\
\hline & 24 & 134.045 & $\mathrm{C}_{4} \mathrm{H}_{8} \mathrm{NO}_{4}$ & - & & Aspartic acid \\
\hline & 200 & 147.076 & $\mathrm{C}_{5} \mathrm{H}_{11} \mathrm{~N}_{2} \mathrm{O}_{3}$ & - & & Glutamine \\
\hline & 60 & 156.077 & $\mathrm{C}_{6} \mathrm{H}_{10} \mathrm{~N}_{3} \mathrm{O}_{2}$ & - & & Histidine \\
\hline 1.32 & 150 & 148.060 & $\mathrm{C}_{5} \mathrm{H}_{10} \mathrm{NO}_{4}$ & - & & Glutamic acid \\
\hline 1.67 & 35 & 150.058 & $\mathrm{C}_{5} \mathrm{H}_{12} \mathrm{NO}_{2} \mathrm{~S}$ & - & & Methionine \\
\hline 1.81 & 300 & 132.102 & $\mathrm{C}_{6} \mathrm{H}_{14} \mathrm{NO}_{2}$ & 86.096 & $\mathrm{C}_{5} \mathrm{H}_{12} \mathrm{~N}$ & $\mathrm{~L} / \mathrm{l}$ \\
\hline 1.88 & 80 & 182.081 & $\mathrm{C}_{9} \mathrm{H}_{12} \mathrm{NO}_{3}$ & - & & Tyrosine \\
\hline 2.76 & 180 & 166.086 & $\mathrm{C}_{9} \mathrm{H}_{12} \mathrm{NO}_{2}$ & - & & Phenylalanine \\
\hline 4.79 & 26 & 205.097 & $\mathrm{C}_{11} \mathrm{H}_{13} \mathrm{~N}_{2} \mathrm{O}_{2}$ & - & & Tryptophan \\
\hline
\end{tabular}


Table 3. Biogenic acines in the crude venom extract from Scolia decorata ventralis by LC-ESI-MS.

\begin{tabular}{|c|c|c|c|c|c|c|}
\hline $\begin{array}{c}\text { RT } \\
(\min )\end{array}$ & $\begin{array}{l}\text { Intensity } \\
\times 10^{4}\end{array}$ & $\begin{array}{c}{[M+H]^{+}} \\
m / z\end{array}$ & $\begin{array}{l}\text { Elemental } \\
\text { composition }\end{array}$ & $\begin{array}{c}\text { Deamination } \\
m / z\end{array}$ & $\begin{array}{l}\text { Elemental } \\
\text { composition }\end{array}$ & Compound \\
\hline \multirow[t]{3}{*}{1.04} & 550 & 112.087 & $\mathrm{C}_{5} \mathrm{H}_{10} \mathrm{~N}_{3}$ & 95.060 & $\mathrm{C}_{5} \mathrm{H}_{7} \mathrm{~N}_{2}$ & Histamine \\
\hline & 10 & 146.165 & $\mathrm{C}_{7} \mathrm{H}_{20} \mathrm{~N}_{3}$ & - & & Spermidine \\
\hline & 25 & 203.223 & $\mathrm{C}_{10} \mathrm{H}_{27} \mathrm{~N}_{4}$ & - & & Spermine \\
\hline 1.67 & 11 & 154.086 & $\mathrm{C}_{8} \mathrm{H}_{12} \mathrm{NO}_{2}$ & 137.060 & $\mathrm{C}_{8} \mathrm{H}_{9} \mathrm{O}_{2}$ & Dopamine \\
\hline 1.88 & 1600 & 138.091 & $\mathrm{C}_{8} \mathrm{H}_{12} \mathrm{NO}$ & 121.065 & $\mathrm{C}_{8} \mathrm{H}_{9} \mathrm{O}$ & Tyramine \\
\hline 2.32 & 6 & 177.102 & $\mathrm{C}_{10} \mathrm{H}_{13} \mathrm{~N}_{2} \mathrm{O}$ & 160.076 & $\mathrm{C}_{10} \mathrm{H}_{10} \mathrm{NO}$ & Serotonin \\
\hline 3.49 & 4 & 146.117 & $\mathrm{C}_{7} \mathrm{H}_{16} \mathrm{NO}_{2}$ & - & & Acetylcholine \\
\hline
\end{tabular}

Table 4. Nucleic acids in the crude venom extract from Scolia decorata ventralis by LC-ESI-MS.

\begin{tabular}{|c|c|c|c|c|}
\hline $\begin{array}{c}\text { RT } \\
\text { (min) }\end{array}$ & $\begin{array}{c}\text { Intensity } \\
\times 10^{4}\end{array}$ & $\begin{array}{c}{[M+H]^{+}} \\
m / z\end{array}$ & $\begin{array}{l}\text { Elemental } \\
\text { composition }\end{array}$ & Compound \\
\hline 1.32 & 200 & 258.110 & $\mathrm{C}_{10} \mathrm{H}_{16} \mathrm{~N}_{3} \mathrm{O}_{5}$ & Thymidine \\
\hline \multirow[t]{3}{*}{1.53} & 60 & 244.093 & $\mathrm{C}_{9} \mathrm{H}_{14} \mathrm{~N}_{3} \mathrm{O}_{5}$ & Cytidine \\
\hline & 16 & 348.070 & $\mathrm{C}_{10} \mathrm{H}_{15} \mathrm{~N}_{5} \mathrm{O}_{7} \mathrm{P}$ & Adenosine monophosphate \\
\hline & 13 & 428.037 & $\mathrm{C}_{10} \mathrm{H}_{16} \mathrm{~N}_{5} \mathrm{O}_{10} \mathrm{P}_{2}$ & Adenosine diphosphate \\
\hline 1.60 & 50 & 664.116 & $\mathrm{C}_{21} \mathrm{H}_{28} \mathrm{~N}_{7} \mathrm{O}_{14} \mathrm{P}_{2}$ & NAD \\
\hline 1.74 & 12 & 245.077 & $\mathrm{C}_{9} \mathrm{H}_{13} \mathrm{~N}_{2} \mathrm{O}_{6}$ & Uridine \\
\hline 1.81 & 2000 & 268.104 & $\mathrm{C}_{10} \mathrm{H}_{14} \mathrm{~N}_{5} \mathrm{O}_{4}$ & Adenosine \\
\hline 1.98 & 30 & 284.099 & $\mathrm{C}_{10} \mathrm{H}_{14} \mathrm{~N}_{5} \mathrm{O}_{5}$ & Guanosine \\
\hline 2.10 & 150 & 269.088 & $\mathrm{C}_{10} \mathrm{H}_{13} \mathrm{~N}_{4} \mathrm{O}_{5}$ & Inosine \\
\hline
\end{tabular}

MS/MS comparisons of the synthetic specimens with the natural peptides finally corroborated the sequences. These peptides can belong to bradykinin-related peptides because the sequences are homologous to those of known bradykinin-related peptides, in particular, to Cd-146 (Table 6).

The analyzed full sequences can be classified according to homology and similarity as shown in Table 7. The major class is bradykinin-related peptides including $\alpha$-scoliidine and $\beta$-scoliidine, and the rest of the classes may be novel peptides because all these have no homology or similarity to any known peptides. Within each class, the longest sequence can be "parent peptide", and others are truncated peptides from both $\mathrm{N}$ - and C-terminus of the parent peptide. Seemingly, these truncated peptides are cleavage products of the parent peptide in some way, but it is not sure whether they are originally contained in the venom or not.

\section{Enzymatic assays}

Both $\alpha$-scoliidine and $\beta$-scoliidine were unable to inhibit the catalytic activity of ACE. In addition, both peptides were not cleaved by the metallopeptidase, indicating that they do not interact with the studied enzyme (Table 8).

\section{Neurotoxicity of $\alpha$-scoliidine and $\beta$-scoliidine}

The cytotoxic effects of both peptides were assessed using the PC12 cell line as illustrated in Figure 2. The $\alpha$-scoliidine did not show any significant cytotoxicity $(p>0.05)$ in all dose concentrations, and at the times tested when compared to the untreated cell (control) or DMSO (Figure 2A). Interestingly, $\beta$-scoliidine decreased cell integrity after $6 \mathrm{~h}$ of treatment in all concentration tested (Figure 2B). However, after 24 and $48 \mathrm{~h}$ of treatment with this peptide, cell integrity increased significantly ( $\mathrm{p}<0.05$ ), especially at 0.1 and $1 \mu \mathrm{M}$, compared to the control group. DMSO decreased the cell integrity after 24 and $48 \mathrm{~h}$ compared to the control group, which is in accordance with the literature [23]. The $\alpha$-scoliidine and $\beta$-scoliidine at $1 \mu \mathrm{M}$ for $24 \mathrm{~h}$ of treatments were chosen to carry out neuroprotective assays.

\section{Neuroprotective effects against $\mathbf{H}_{2} \mathbf{O}_{2}$-induced oxidative stress}

The neuroprotective effects against $\mathrm{H}_{2} \mathrm{O}_{2}$-induced oxidative stress in the presence of $\alpha$-scoliidine and $\beta$-scoliidine were studied in PC12 cells using two experimental conditions of treatments (Figures 3 and 4). In the first assay (Figure 3A), $\mathrm{H}_{2} \mathrm{O}_{2}$ was cytotoxic at concentrations greater than $0.5 \mathrm{mM}$ 
Table 5. Peptide sequences analyzed from MS/MS spectra.

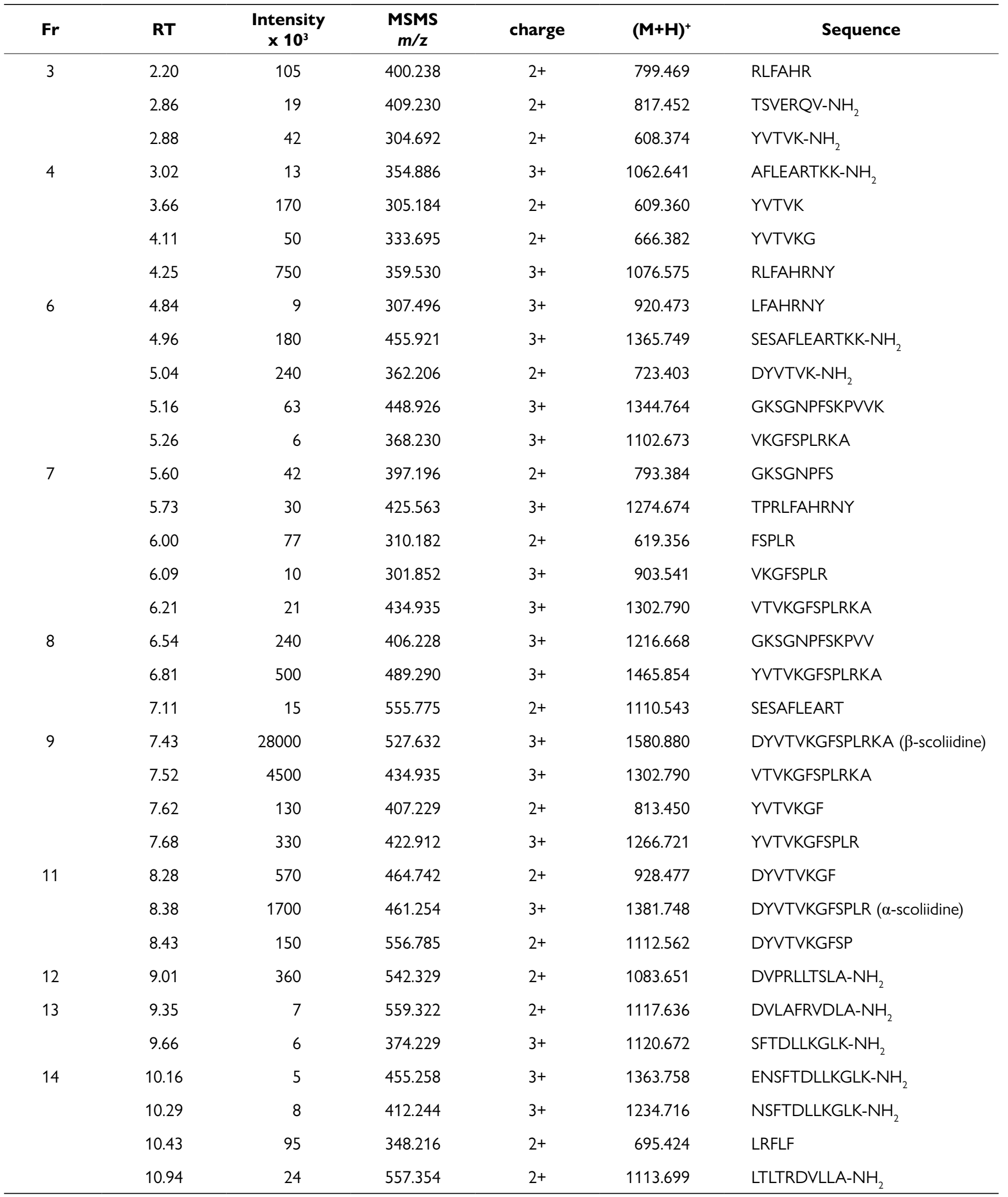


Table 6. Bradykinin-related peptides in solitary wasp venoms.

\begin{tabular}{lr}
\hline Peptides & Sequence \\
\hline Thr6-Bradykinin & RPPGFTPFR \\
Megascoliakinin & RPPGFTPFRKA \\
Cyphokinin & DTRPPGFTPFR \\
Fulvonin & SIVLRGKAPFR \\
Cd-146 & SETGNTVTKGFSPLR \\
$\alpha-S c o l i i d i n e$ & DYVTVKGFSPLR \\
$\beta$-Scoliidine & DYVTVKGFSPLRKA \\
\hline
\end{tabular}

Table 7. Classification of the peptide sequences.

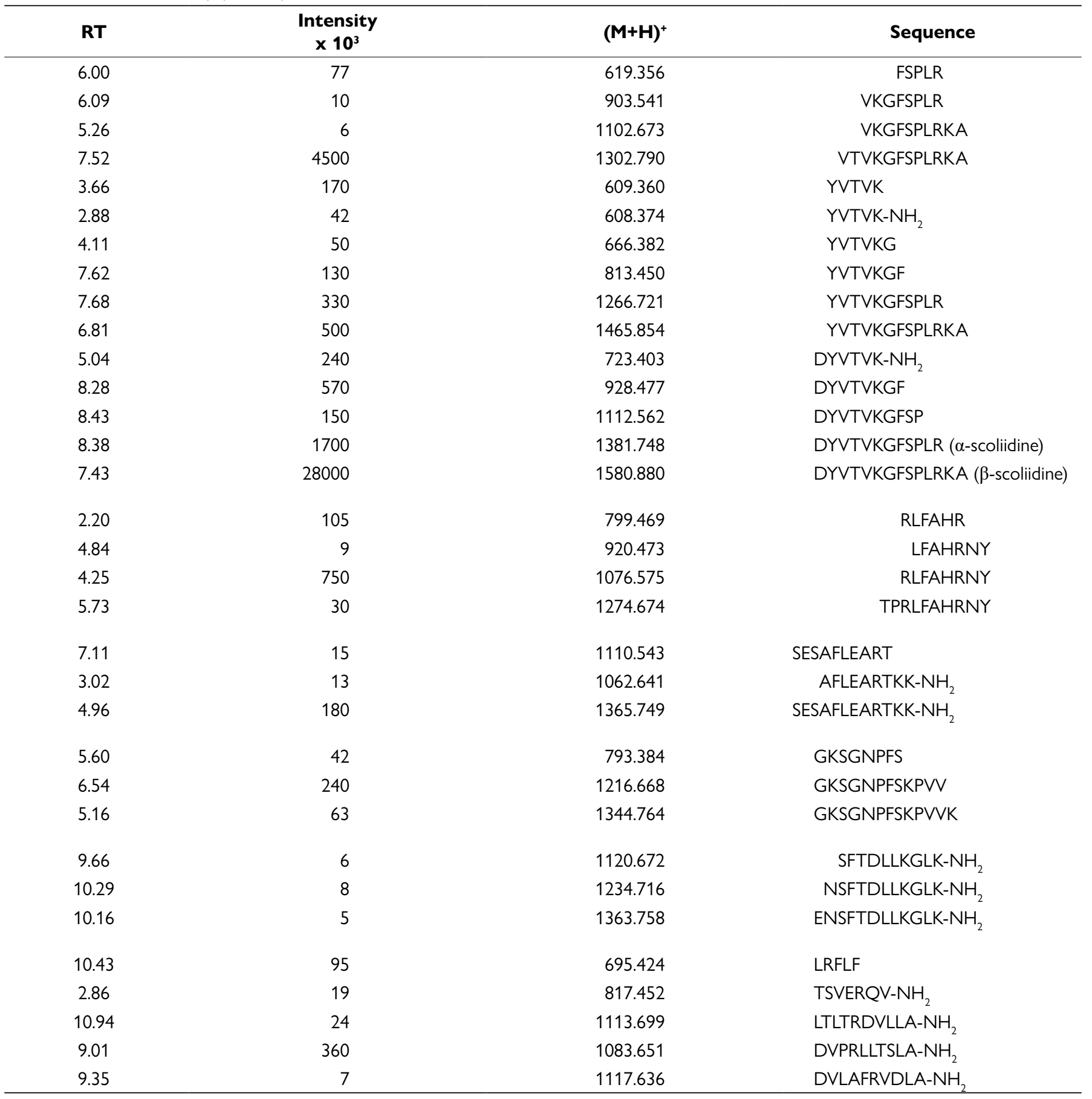


Table 8. Hydrolyses of $\alpha$-scoliidine and $\beta$-scoliidine by human neprilysin (NEP) and angiotensin-converting enzyme (ACE).

\begin{tabular}{|c|c|c|c|c|}
\hline & \multicolumn{2}{|c|}{ Inhibition (\%) } & \multicolumn{2}{|c|}{ Cleavage (\%) } \\
\hline & ACE & NEP & ACE & NEP \\
\hline$\alpha$-scoliidine & $<0.01$ & $<0.01$ & $<0.01$ & $<0.01$ \\
\hline$\beta$-scoliidine & $<0.01$ & $<0.01$ & $<0.01$ & $<0.01$ \\
\hline
\end{tabular}
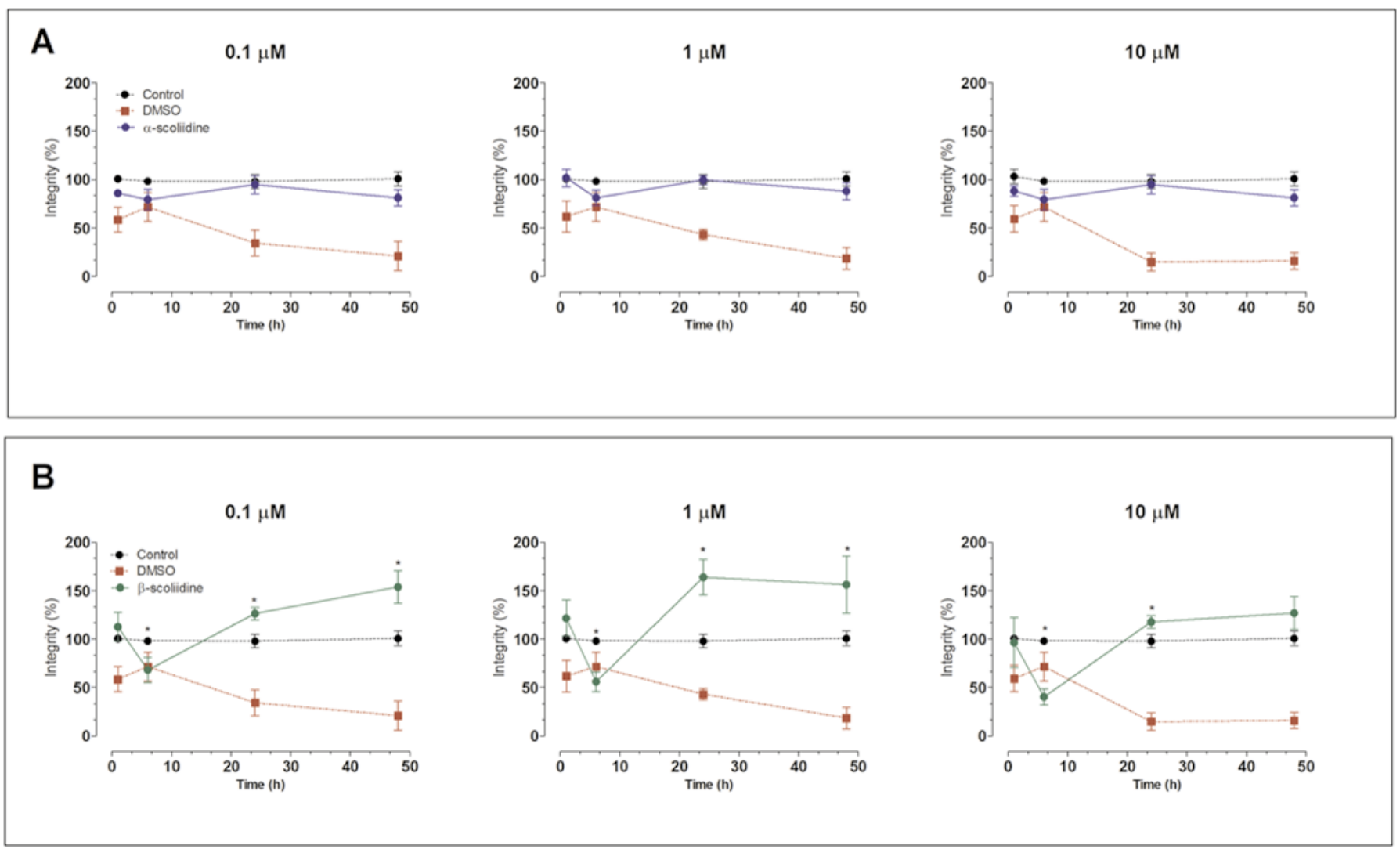

Figure 2. Effect of $\alpha$-scoliidine and $\beta$-scoliidine on cell viability in PC12 cells. Cells treated with either (A) $\alpha$-scoliidine or (B) $\beta$-scoliidine in concentrations varying from 0.1 to $10 \mu \mathrm{M}$ for 3, 6, 12, 24, and $48 \mathrm{~h}$. Control and DMSO groups represent cell without treatment and treated with DMSO $2.5 \%$, respectively. Values are expressed as mean \pm standard deviation from three independent experiments in triplicate and analyzed by one-way ANOVA followed by Tukey's post-test. ${ }^{*} p<0.05$ in relation to the control group.

after $24 \mathrm{~h}$ of treatment, showing a dose-response effect. Thus, $0.6 \mathrm{mM}$ of $\mathrm{H}_{2} \mathrm{O}_{2}$ was chosen for subsequent studies (Figure 3B). The $\alpha$-scoliidine and $\beta$-scoliidine $(1 \mu \mathrm{M})$ pre-treatment did not prevent the reduction of cell integrity, but significantly increased the $\mathrm{H}_{2} \mathrm{O}_{2}$-induced toxicity (Figure $3 \mathrm{C}$ ). In the second assay (Figure $4 \mathrm{~A}$ ), $\mathrm{H}_{2} \mathrm{O}_{2}$ also showed a dose-response effect after $24 \mathrm{~h}$ of treatment, as in the first neuroprotective assay, and $0.6 \mathrm{mM}$ dose was chosen for further studies (Figure 4B). Pre-treatment with $\beta$-scoliidine increased the integrity of PC12 cells exposed to oxidative stress compared with to control $\left(\mathrm{H}_{2} \mathrm{O}_{2}\right)$ (Figure $4 \mathrm{C}$ ). Besides, cells pre-treated with $\alpha$-scoliidine did not present significant differences against $\mathrm{H}_{2} \mathrm{O}_{2}$-induced oxidative stress.

\section{Neuroprotective property on mitochondrial metabolism}

Neuroprotective properties of $\alpha$-scoliidine or $\beta$-scoliidine on mitochondrial metabolism of the $\mathrm{PC} 12$ cell line against $\mathrm{H}_{2} \mathrm{O}_{2}$ induced oxidative stress were investigated in the present study (Figure 5). Cells treated with $\mathrm{H}_{2} \mathrm{O}_{2}$ for $20 \mathrm{~h}$ decreased metabolic viability to $32.23 \pm 0.96 \%$. Cells pre-treated with $\alpha$-scoliidine did not prevent the reduction of metabolic viability caused by $\mathrm{H}_{2} \mathrm{O}_{2}$. On the other hand, $\beta$-scoliidine attenuated in $50 \%$ the $\mathrm{H}_{2} \mathrm{O}_{2}$-induced metabolic viability reduction. The protective properties against $\mathrm{H}_{2} \mathrm{O}_{2}$-induced cytotoxicity of L-Name $(1 \mathrm{mM})$ and the $\mathrm{Bk}(0.30 \mu \mathrm{M})$ were also evaluated in our study. L-Name 

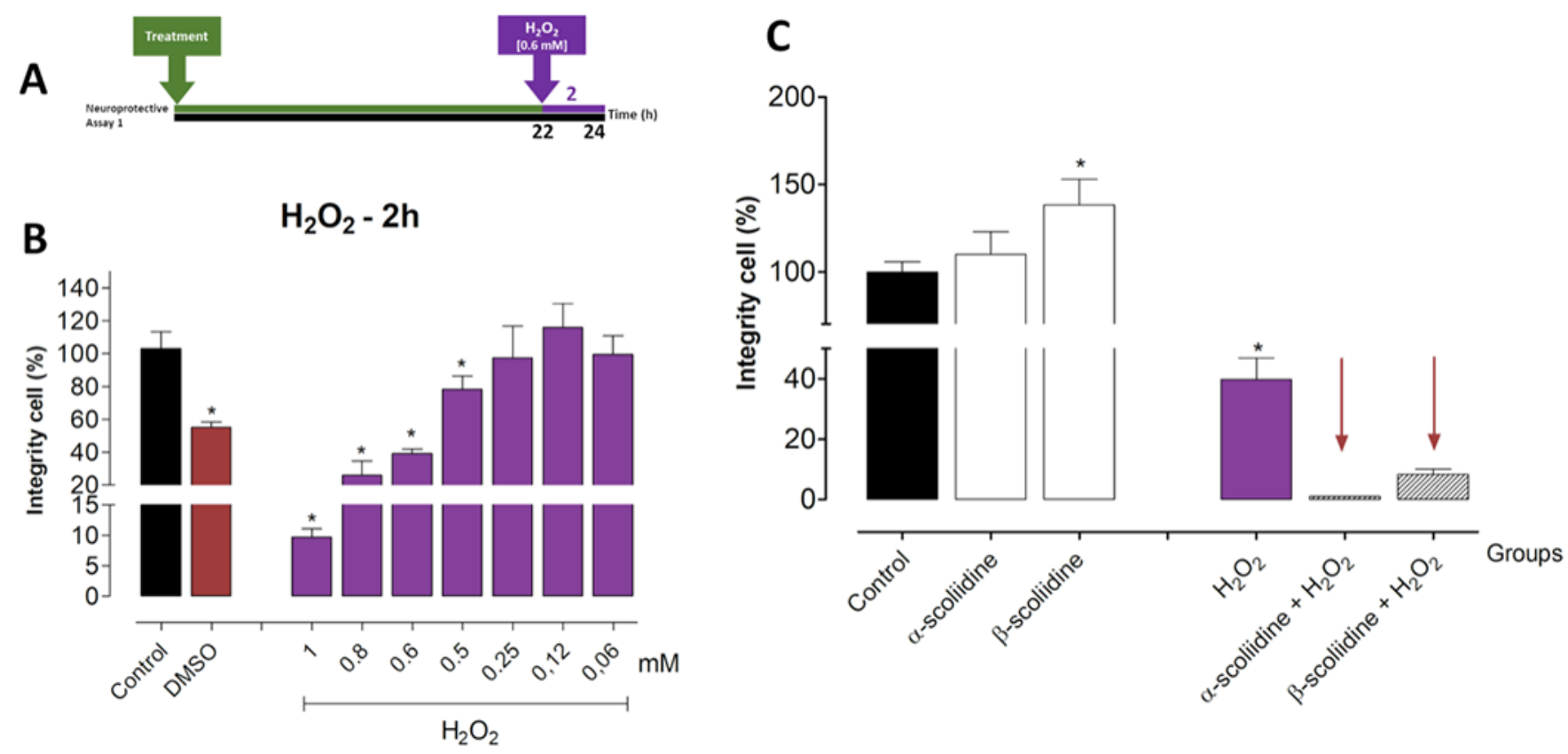

Figure 3. Effect of acute $\mathrm{H}_{2} \mathrm{O}_{2}$-induced oxidative stress on cell viability and neuroprotective evaluation of either $\alpha$-scoliidine or $\beta$-scoliidine in PC12 cells. PC12 cells were seeded at $2 \times 10^{4}$ cells/well in a 96-well plate for $24 \mathrm{~h}$, and then submitted to different treatment. (A) Neuroprotective assay scheme where cells were treated with $\alpha$-scoliidine or $\beta$-scoliidine $(1 \mu \mathrm{M})$ for $22 \mathrm{~h}$ at $37^{\circ} \mathrm{C}$ and, after the medium were replaced containing peptide and $\mathrm{H}_{2} \mathrm{O}_{2}(0.6 \mathrm{mM})$ and incubated for more 2 h. (B) Dose-response of $\mathrm{H}_{2} \mathrm{O}_{2}$ for concentrations varying between 1-0.06 mM for 2 h. (C) Protective effects of $\alpha$-scoliidine or $\beta$-scoliidine against oxidative stress-induced neurotoxicity. Values are expressed as mean \pm standard deviation from three independent experiments in triplicate and analyzed by oneway ANOVA followed by Tukey's post-test. $* p<0.05$ to differences among the control group.
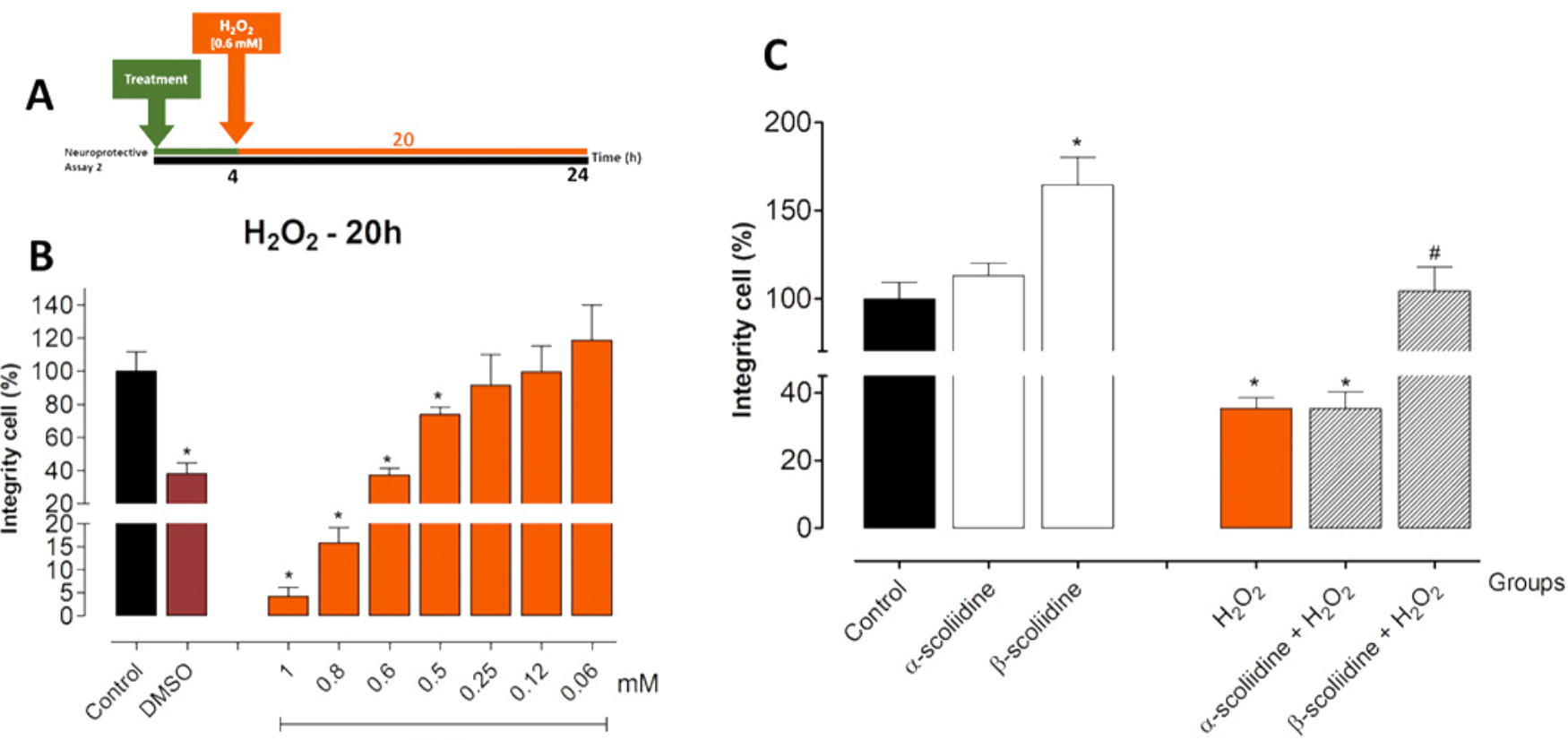

Figure 4. Effect of chronic $\mathrm{H}_{2} \mathrm{O}_{2}$-induced oxidative stress on cell viability and neuroprotective evaluation of either $\alpha$-scoliidine or $\beta$-scoliidine in PC12 cells. PC12 cells were seeded at $2 \times 10^{4}$ cells/well in a 96 -well plate for $24 \mathrm{~h}$, and then submitted to different treatment. (A) Neuroprotective assay scheme where cells were treated with $\alpha$-scoliidine or $\beta$-scoliidine $(1 \mu \mathrm{M})$ for $4 \mathrm{~h}$ at $37^{\circ} \mathrm{C}$ and, after the medium were replaced containing peptide and $\mathrm{H}_{2} \mathrm{O}_{2}(0.6 \mathrm{mM})$ and incubated for more 20 h. (B) Dose-response of $\mathrm{H}_{2} \mathrm{O}_{2}$ for concentrations varying between 1-0.06 mM for $20 \mathrm{~h}$. (C) Protective effects of $\alpha$-scoliidine or $\beta$-scoliidine against oxidative stress-induced neurotoxicity. The cell integrity was analyzed by crystal violet protocol. Values are expressed as mean \pm standard deviation from three independent experiments in triplicate and analyzed by one-way ANOVA followed by Tukey's post-test. $* p<0.05$ to differences among the control group, \# $p<$ 0.05 when compared with the $\mathrm{H}_{2} \mathrm{O}_{2}$ group. 


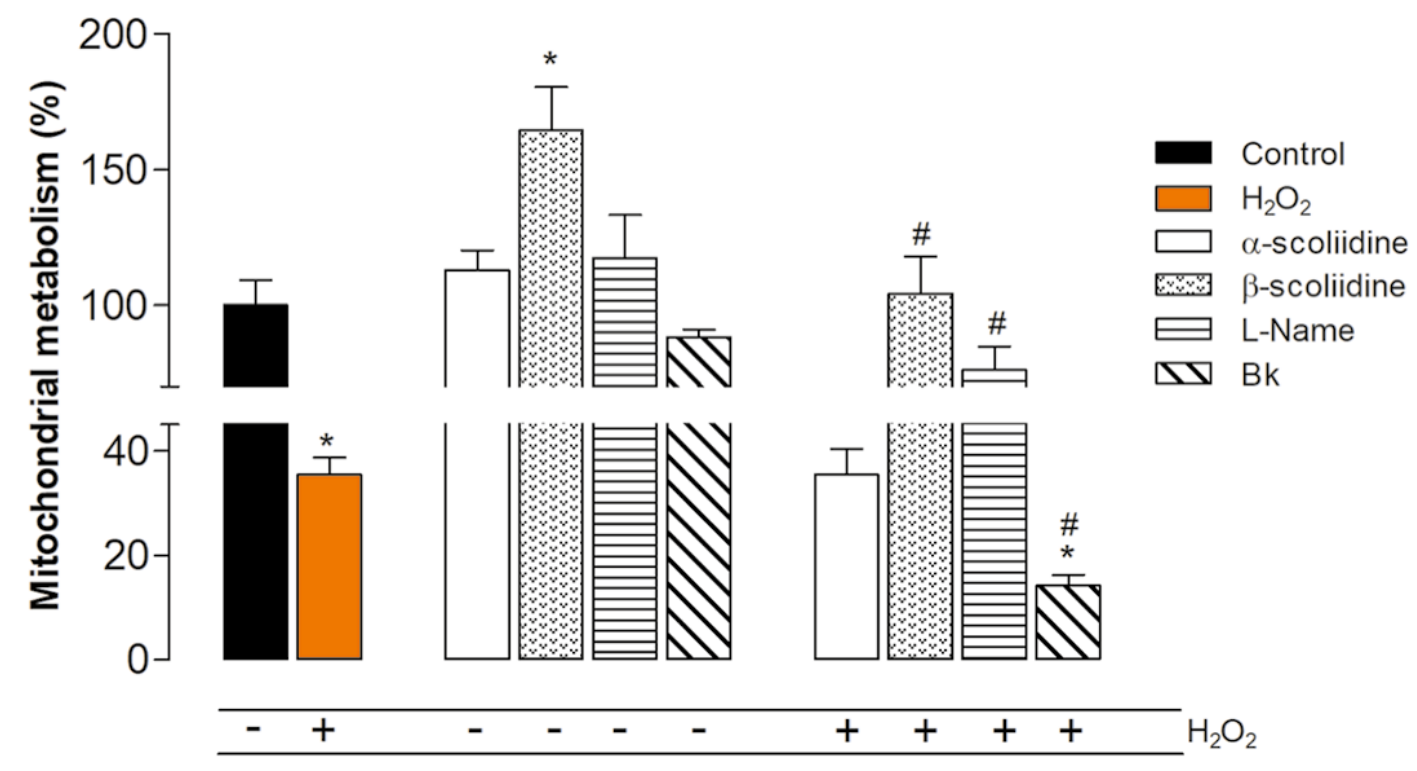

Figure 5. Neuroprotective property of $\alpha$-scoliidine or $\beta$-scoliidine on mitochondrial metabolism of the PC12 cell line against $\mathrm{H}_{2} \mathrm{O}_{2}$-induced oxidative stress. PC12 cells were seeded at $2 \times 10^{4}$ cells/well in a 96 -well plate for $24 \mathrm{~h}$, and treated with $\alpha$-scoliidine or $\beta$-scoliidine $(1 \mu \mathrm{M})$ for $4 \mathrm{~h}$ at $37^{\circ} \mathrm{C}$ and, after the medium were replaced containing peptide and $\mathrm{H}_{2} \mathrm{O}_{2}(0.6 \mathrm{mM})$ and incubated for more $20 \mathrm{~h}$. Mitochondrial metabolism activity was assessed using 3-(4,5-dimethylthiazol2-yl)-2,5-diphenyltetrazolium bromide (MTT) protocol. Values are expressed as mean \pm standard deviation from three independent experiments in triplicate and analyzed by one-way ANOVA followed by Tukey's post-test. ${ }^{*} p<0.05$ to differences among the control group. \# $p<0.05$ when compared with the $\mathrm{H}_{2} \mathrm{O}_{2}$ group. L-Name: L-N²-Nitroarginine methyl ester; Bk: Bradykinin.

pre-treatment prevented the reduction of metabolic viability. In contrast, $\mathrm{Bk}$ decreased the metabolic viability compared with the $\mathrm{H}_{2} \mathrm{O}_{2}$ group.

\section{Discussion}

In this study, we have first analyzed the component profile of the crude venom extract of Scolia decorata ventralis, a solitary scoliid wasp inhabiting in Japan, by using LC-ESI-MS and MS/ MS. It revealed that this venom contained 123 components and a majority of them are small peptides. The peptide sequences were further analyzed by manual analysis of their MS/MS spectra, which led to the determination of full sequence of 33 peptides. Among them, two major peptides, $\alpha$ - and $\beta$-scoliidine, were thought to be bradykinin-related peptides due to the sequence similarity to bradykinin-related peptides from solitary wasp venoms. Many of the minor peptides are related to and truncated form of these scoliidine peptides. It is not sure whether they are constitutive of the venom or degradation products of the scoliidine peptides. In any case, they are of interest in viewpoint of structure-activity relationship, which may be a future study. Other than these bradykinin-related peptides, there found 4 different classes of unique peptide components in this venom. But, their function and role in this venom are not clear since they have no homology or similarity to any known peptides. In addition to the peptides, we identified 33 small molecules (amino acids, biogenic amines and nucleic acids). It was done easily and simply by LC-MS and MS/MS analysis as reported previously [19]. Previous studies reported the presence and function of some of these components in wasp venoms. Two most abundant biogenic amines, histamine and tyramine, were reported to be found in social and solitary wasp venoms, playing a role in painproducing component [20]. Adenosine is contained in solitary spider wasp venoms [24]. Dopamine is resent in the venom of emerald jewel wasp Ampulex compressa and implicated in a unique behavior of its prey, American cockroach [21]. Most of the small molecules contained in this wasp venom would give physiological effect when injected into beetle larvae prey, which is remained to be studied.

Most notably, these results were obtained by using only $10 \%$ amount of a single venom content. Among the Hymenopteran insect venoms, solitary wasp venom has not been well documented. One of the reasons why may come from the difficulty of collecting sufficient amount of venom for chemical analysis because of their solitary lifestyle. However, as shown in this and previous study [19], the remarkable progress of mass spectrometry in sensitivity made it possible to perform this type of peptidomic analysis with very minute amount of venom.

Solitary wasp venoms are a rich source of neuroactive substances, as their venoms induce paralysis in their prey, keeping them alive to feed their larvae [25]. The first components characterized in solitary wasp venom were bradykininrelated peptides [11] which block the synaptic transmission of the nAChR $[12,14]$. Other neurotoxins potentiate synaptic transmission of lobster leg muscle by presynaptic mechanisms, as pompilidotoxins $[6,7]$. Here, we evaluated, for the first time, the neurotoxicity of $\alpha$-scoliidine and $\beta$-scoliidine, two main peptides characterized in the Scolia decorata ventralis' venom, on the neuronal PC12 cell line. Interestingly, $\alpha$-scoliidine was not cytotoxic in all concentrations and times tested, in contrast 
to $\beta$-scoliidine, which was cytotoxic after $3 \mathrm{~h}$ of treatment in all concentrations tested. Despite that, $\beta$-scoliidine increased the number of cells. The most pronounced effect was obtained with the dose of $1 \mu \mathrm{M}$, after 24 to $48 \mathrm{~h}$ of treatment, suggesting that this peptide increases the cell rate proliferation.

Oxidative stress is a condition in which the balance between the production of reactive oxygen species (ROS) and the level of antioxidants is considerably altered, and has been associated with the progression of different neurodegenerative diseases [26]. These diseases use experimental models, such as animals and cell cultures, to understand how oxidative stress can produce neurotoxic effects $[26,27]$.

The cellular stress model used in this work was based on the $\mathrm{H}_{2} \mathrm{O}_{2}$-induced oxidative stress, which stimulates the excessive production of ROS [27] in neuronal cell lines after acute and chronic treatments. In our study, using PC12 cells, $\mathrm{H}_{2} \mathrm{O}_{2}$ promoted cell death in a dose-dependent manner in both protocols performed, and we adopted the $0.6 \mathrm{mM} \mathrm{H}_{2} \mathrm{O}_{2}$ concentration to reduce $\sim 60 \%$ cell viability, as reported in other studies $[17,18,28-30]$. Then, we investigated the neuroprotective effects of $\alpha$-scoliidine and $\beta$-scoliidine against $\mathrm{H}_{2} \mathrm{O}_{2}$-induced oxidative stress in PC12 cells treated with $\mathrm{H}_{2} \mathrm{O}_{2}$ at $0.6 \mathrm{mM}$ for 2 $\mathrm{h}$ or $18 \mathrm{~h}$ - acute and chronic treatments, respectively.

The acute treatment was not a satisfactory experimental design, since both scoliidines potentiated cell damage mediated by $\mathrm{H}_{2} \mathrm{O}_{2}$, especially the treatment with $\beta$-scoliidine. In the acute treatment, $\beta$-scoliidine was neurotoxic and $\alpha$-scoliidine showed a tendency for neurotoxicity at $6 \mathrm{~h}$ of treatment, which could explain the increase of $\mathrm{H}_{2} \mathrm{O}_{2}$-mediated neuronal damage. The phenomenon of synergistic toxicity of $\mathrm{H}_{2} \mathrm{O}_{2}$ effects when two agents are used together, and efficiently potentiate cell damage, has been reported in the literature [31]. Of the several examples of $\mathrm{H}_{2} \mathrm{O}_{2}$ toxicity potentiation by other simple chemicals, the best-known case is observed in immune cells with a mixture of $\mathrm{H}_{2} \mathrm{O}_{2}$ and nitric oxide (NO), during the infectious process [32]. Besides, a few other inorganic molecules also potentiate $\mathrm{H}_{2} \mathrm{O}_{2}$ toxicity in mammalian cells [31]. The enhancement of the intracellular oxidative potential of $\mathrm{H}_{2} \mathrm{O}_{2}$ by ascorbic acid, for example, is also reported [33]. Many cancer cell lines are sensitive to extracellular concentrations of ascorbic acid, which are harmless to normal cells. This sensitivity is alleviated by extracellular catalase, indicating that ascorbic acid, associated with $\mathrm{H}_{2} \mathrm{O}_{2}$ toxicity, is the underlying cause of its sensitivity [34]. For these reasons, further studies are needed to explain the potentiating effects of $\mathrm{H}_{2} \mathrm{O}_{2}$ toxicity in the presence of scoliidines.

Neurogenesis and neuroprotection might be stimulated by Bk, being of great interest in clinical applications following brain injury [35]. Bk simultaneously reduces the rate of proliferation and the neuronal enrichment of rat embryonic telencephalon neural precursor cells [36]. In the present study, Bk changed the proliferation rate of $\mathrm{PC} 12$ cells, reducing the metabolic viability at $24 \mathrm{~h}$ of treatment compared with the control and $\mathrm{H}_{2} \mathrm{O}_{2}$ groups. The two main peptides identified from the Scolia decorata ventralis venom were $\alpha$-scoliidine (DYVTVKGFSPLR) and $\beta$-scoliidine (DYVTVKGFSPLRKA) which present homology with the bradykinin C-terminal (RPPGFSPFR), suggesting, therefore, similar activities. For these reasons, both synthetic peptides have been evaluated as possible inhibitors or substrates for ACE, but negative results have shown that scoliidines do not interact with this metallopeptidase. Neuroprotection studies indicated that $\alpha$-scoliidine, which is similar to the Bk (GFSPFR), did not alter cell proliferation, but both peptides showed different protective effects against neurotoxicity induced by oxidative stress in the PC12 cell.

A neuroprotective compound can diminish the molecular and cellular ROS-mediated damages, preventing or attenuating the progression of the disease and its secondary consequences $[26,35]$. Studies reported that small structural differences in bioactive peptides promoted remarkable functional differences $[6,11,17,18]$. Bradykinin-potentiating peptides (BPPs) from the Bothrops jararaca snake venom were described as neuroprotective against $\mathrm{H}_{2} \mathrm{O}_{2}$-induced oxidative stress in human neuroblast-like cell line SH-SY5Y [17,18]. BPP-11e (<EARPPHPPIPP) and BPP-AP ( $<$ EARPPHPPIPPAP), for example, are not good neuroprotective peptides against the $\mathrm{H}_{2} \mathrm{O}_{2}$-induced oxidative stress [18] in contrast to the BPP-10c ( $<$ ENWPHQIPP) [17]. This fact was also observed in the present study, where small structural differences between the two scoliidines resulted in significant differences in biological activities. That is, $\beta$-scoliidine demonstrated neuroprotective effect against the $\mathrm{H}_{2} \mathrm{O}_{2}$-induced damage, preserving neuronal cell integrity and mitochondrial metabolism in chronic treatment, but not $\alpha$-scoliidine. It is very interesting to note that the $\beta$-scoliidine effects were dependent on the presence of only two more amino acid residues (KA) in the C-terminal on its primary molecular sequence. Besides, $\beta$-scoliidine also increased cell proliferation in contrast to $\alpha$-scoliidine. Previous works have shown that amyloid- $\beta$ peptide $(A \beta)$ isoforms found in amyloid plaques of brains with Alzheimer's disease can affect differentiation and proliferation of rat or mouse neural progenitor cells $[37,38]$. Specifically, A $\beta 42$ peptide isoform promotes cell proliferation of human neural stem cells in a concentrationdependent manner [39]. Dexmedetomidine (DEX) protected PC12 cells from ROS-induced cytotoxicity via inhibition of collagen alpha-1(III) chain expression and mitogen-activated protein kinase (MAPK) pathway activation [40,41]. DEXmediated neuroprotection is associated with a dose-dependent restored impaired proliferation of PC12 cells in a stress condition, as reflected by the increased cell viability, which were consistent with the decreased expression of tumor suppressor protein $\mathrm{p} 21$ and increased expression of cell cycle-related cyclin D1 [42]. Interestingly, these data indicate that neuroprotective effects of $\beta$-scoliidine against $\mathrm{H}_{2} \mathrm{O}_{2}$-induced oxidative stress could be explained by the increased cell proliferation in PC12 cells. Despite that, more studies are needed to better clarify the mechanism underlying how $\beta$-scoliidine induces cell proliferation, and its relation to the neuroprotective effect. 


\section{Conclusions}

Comprehensive LC-MS and MS/MS analyses of the crude venom extract from the solitary scoliid wasp Scolia decorata ventralis revealed the component profile of this venom. The two major peptide components, $\alpha$-scoliidine and $\beta$-scoliidine, are bradykinin-related peptides. $\beta$-scoliidine showed an effective cytoprotective effect, probably due to the observed increase in the cell number. This is the first case for solitary wasp venom peptides to show neuroprotective activity.

\section{Abbreviations}

ACE: angiotensin-converting enzyme; ANOVA: one-way analysis of variance; ASIC: acid-sensing ion channels; $A \beta$ : amyloid- $\beta$ peptide; Bk: bradykinin; BPPs: bradykinin-potentiating peptides; DEX: dexmedetomidine; DMEM: Dulbecco's modified Eagle's medium; DMSO: dimethyl sulfoxide; FRET: fluorescence resonance energy transfer; HPLC: high performance liquid chromatography; LC-MS: liquid chromatography-mass spectrometry; L-Name: L-N $\Omega$-Nitroarginine methyl ester; MALDI-TOF MS: matrix assisted laser desorption/ionization time-of-flight mass spectrometry; MAPK: mitogen-activated protein kinase; MTT: 3-(4,5-dimethylthiazol-2-yl)-2,5diphenyltetrazolium bromide; $\mathrm{nAChR}$ : nicotinic acetylcholine receptor; NEP: human neprilysin; PC12: neuronal cell line derived from a transplantable rat pheochromocytoma; ROS: reactive oxygen species; $\mathrm{SD}$ : standard deviation; $\mathrm{Thr}^{6}-\mathrm{BK}$ : threonine6-bradykinin; TIC: total ion current.

\section{Availability of data and materials}

All data generated or analyzed during this study are included in this published article.

\section{Funding}

This work was supported by the State of São Paulo Research Foundation (FAPESP) and the Coordination for the Improvement of Higher Education Personnel (CAPES) (Finance Code 001).

\section{Competing interests}

The authors declare that they have no competing interests.

\section{Authors' contributions}

FCVP, RTK, and MR designed this work. KN performed MALDI TOF/TOF MS experiment and analysis. CAS and HQP performed neuroprotective experiments in PC12 cells. KK performed LCESI-MS and MS/MS experiments and analysis. KK, FCVP, and CAS designed this work, and were responsible for drafting the manuscript. All authors read and approved the final manuscript.

\section{Ethics approval}

Not applicable.

\section{Consent for publication}

Not applicable.

\section{References}

1. Rádis-Baptista G, Konno K. Arthropod venom components and their potential usage. Toxins (Basel). 2020 Feb;12(2):82.

2. Saez NJ, Herzig V. Versatile spider venom peptides and their medical and agricultural applications. Toxicon. 2019 Feb;158:109-26.

3. Ortiz E, Gurrola GB, Schwartz EF, Possani LD. Scorpion venom components as potential candidates for drug development. Toxicon. 2015 Jan;93:125-35.

4. Silva J, Monge-Fuentes V, Gomes F, Lopes K, dos Anjos L, Campos G, et al. Pharmacological alternatives for the treatment of neurodegenerative disorders: Wasp and bee venoms and their components as new neuroactive tools. Toxins (Basel). 2015 Aug;7(8):3179-209.

5. O'Neill KM. Solitary wasps: behavior and natural history. Choice Rev Online. 2001.

6. Konno K, Hisada M, Itagaki Y, Naoki H, Kawai N, Miwa A, et al. Isolation and structure of pompilidotoxins, novel peptide neurotoxins in solitary wasp venoms. Biochem Biophys Res Commun. 1998 Sep 29;250(3):612-6.

7. Konnoa K, Kawai N. Pompilidotoxins: Novel peptide neurotoxins blocking sodium channel inactivation from solitary wasp venom. Curr Med Chem. 2004;4(2):139-46.

8. Hernández C, Konno K, Salceda E, Vega R, Zaharenko AJ, Soto E. Sa12b peptide from solitary wasp inhibits ASIC currents in rat dorsal root ganglion neurons. Toxins (Basel). 2019 Oct 10;11(10):585.

9. Picolo G, Hisada M, Moura AB, Machado MFM, Sciani JM, Conceição $I M$, et al. Bradykinin-related peptides in the venom of the solitary wasp Cyphononyx fulvognathus. Biochem Pharmacol. 2010 Feb 1;79(3):478-86.

10. Cabrera MPDS, Rangel M, Ruggiero Neto J, Konno K. Chemical and biological characteristics of antimicrobial $\alpha$-helical peptides found in solitary wasp venoms and their interactions with model membranes. Toxins (Basel). 2019 Oct;11(10):559.

11. Konno K, Kazuma K, Nihei K. Peptide toxins in solitary wasp venoms. Toxins (Basel). 2016 Apr 18;8(4):114.

12. Piek T, Hue B, Mantel P, Nakajima T, Pelhate M, Yasuhara T. Threonine6bradykinin in the venom of the wasp Colpa interrupta (F.) presynaptically blocks nicotinic synaptic transmission in the insect CNS. Comp Biochem Physiol Part C Comp Pharmacol. 1990;96(1):157-62.

13. Yasuhara T, Mantel P, Nakajima T, Piek T. Two kinins isolated from an extract of the venom reservoirs of the solitary wasp Megascolia flavifrons. Toxicon. 1987;25(5):527-35.

14. Piek T, Hue B, Mony L, Nakajima T, Pelhate M, Yasuhara T. Block of synaptic transmission in insect CNS by toxins from the venom of the WASP Megascolia flavifrons (FAB.). Comp Biochem Physiol Part C, Comp Pharmacol Toxicol. 1987;87(2):287-95.

15. Konno K, Palma MS, Hitara IY, Juliano MA, Juliano L, Yasuhara T. Identification of bradykinins in solitary wasp venoms. Toxicon. 2002 Mar;40(3):309-12.

16. Feoktistova M, Geserick P, Leverkus M. Crystal violet assay for determining viability of cultured cells. Cold Spring Harb Protoc. 2016 Apr 1;2016(4):343-6.

17. Querobino SM, Ribeiro CAJ, Alberto-Silva C. Bradykinin-potentiating peptide-10C, an argininosuccinate synthetase activator, protects against $\mathrm{H}_{2} \mathrm{O}_{2}$-induced oxidative stress in $\mathrm{SH}-\mathrm{SY} 5 \mathrm{Y}$ neuroblastoma cells. Peptides. 2018 May;103:90-7.

18. Querobino SM, Costa MS, Alberto-Silva C. Protective effects of distinct proline-rich oligopeptides from $B$. jararaca snake venom against oxidative stress-induced neurotoxicity. Toxicon. 2019 Sep;167:29-37.

19. Konno K, Kazuma K, Rangel M, Stolarz-de-Oliveira J, Fontana R, Kawano $M$, et al. New mastoparan peptides in the venom of the solitary eumenine wasp Eumenes micado. Toxins (Basel). 2019 Mar;11(3):155. 
20. Nakajima T, Yasuhara T, Yoshida N, Takemoto Y, Shinonaga S, Kano R, et al. The pattern analysis of biologically active amines in some Hymenopteran venoms by high performance liquid chromatography. Med Entomol Zool. 1983;34(2):61-71.

21. Moore EL, Arvidson R, Banks C, Urenda JP, Duong E, Mohammed H, et al. Ampulexins: a new family of peptides in venom of the emerald jewel wasp, Ampulex compressa. Biochemistry. 2018 Mar 27;57(12):1907-16.

22. Hisada M, Satake H, Masuda K, Aoyama M, Murata K, Shinada T, et al. Molecular components and toxicity of the venom of the solitary wasp, Anoplius samariensis. Biochem Biophys Res Commun. 2005 May 20;330(4):1048-54.

23. Yi X, Liu M, Luo Q, Zhuo H, Cao H, Wang J, et al. Toxic effects of dimethyl sulfoxide on red blood cells, platelets, and vascular endothelial cells in vitro. FEBS Open Bio. 2017 Feb 20;7(4):485-94.

24. Konno K, Hisada M, Naoki H, Itagaki Y, Yasuhara T, Juliano MA, et al. Isolation and sequence determination of peptides in the venom of the spider wasp (Cyphononyx dorsalis) guided by matrix-assisted laser desorption/ionization time of flight (MALDI-TOF) mass spectrometry. Toxicon. 2001;39:1257-60.

25. Lee SH, Baek JH, Yoon KA. Differential properties of venom peptides and proteins in solitary vs. social hunting wasps. Toxins (Basel). 2016 Jan 22;8(2):32.

26. Gandhi S, Abramov AY. Mechanism of oxidative stress in neurodegeneration. Oxid Med Cell Longev. 2012;2012:428010.

27. Aksenova M, Aksenov M, Mactutus C, Booze R. Cell culture models of oxidative stress and injury in the central nervous system. Curr Neurovasc Res. 2005 Jan;2(1):73-89.

28. Chen FY, Li HT, Li CJ, Chen J, Huang JW, Li C, et al. Neuroprotective racemic germacranolides from the roots of Chloranthus henryi. Fitoterapia. 2020 Mar;141.

29. Sun T, Zhang S, Yang W, Zhao Z, Yang D. Housefly pupae-derived antioxidant peptides exerting neuroprotective effects on hydrogen peroxide-induced oxidative damage in PC12 cells. Molecules. 2019 Dec 7;24(24):4486

30. Wu Y, Qin D, Yang H, Wang W, Xiao J, Zhou L, et al. Neuroprotective effects of deuterium-depleted water (DDW) against $\mathrm{H}_{2} \mathrm{O}_{2}$-induced oxidative stress in differentiated PC12 cells through the PI3K/Akt signaling pathway. Neurochem Res. 2020 May;45(5):1034-44.
31. Mahaseth T, Kuzminov A. Potentiation of hydrogen peroxide toxicity: From catalase inhibition to stable DNA-iron complexes. Mutat Res. 2017 Jul;773:274-81.

32. Pacelli R, Wink DA, Cook JA, Krishna MC, DeGraff W, Friedman N, et al. Nitric oxide potentiates hydrogen peroxide-induced killing of Escherichia coli. J Exp Med. 1995 Nov 1;182(5):1469-79.

33. Inai $\mathrm{Y}, \mathrm{Bi} \mathrm{W}$, Shiraishi N, Nishikimi M. Enhanced oxidative stress by L-ascorbic acid within cells challenged by hydrogen peroxide. J Nutr Sci Vitaminol (Tokyo). 2005 Dec;51(6):398-405.

34. McCarty MF, Contreras F. Increasing superoxide production and the labile iron pool in tumor cells may sensitize them to extracellular ascorbate. Front Oncol. 2014 Sep 16;4:249.

35. Negraes PD, Trujillo CA, Pillat MM, Teng YD, Ulrich H. Roles of kinins in the nervous system. Cell Transplant. 2015;24(4):613-23.

36. Pillat MM, Cheffer A, de Andrade CM, Morsch VM, Schetinger MRC, Ulrich $\mathrm{H}$. Bradykinin-induced inhibition of proliferation rate during neurosphere differentiation: Consequence or cause of neuronal enrichment? Cytometry A. 2015 Oct;87(10):929-35.

37. Itokazu Y, Yu RK. Amyloid $\beta$-peptide 1-42 modulates the proliferation of mouse neural stem cells: upregulation of fucosyltransferase IX and notch signaling. Mol Neurobiol. 2014 Aug;50(1):186-96.

38. Heo C, Chang KA, Choi HS, Kim HS, Kim S, Liew H, et al. Effects of the monomeric, oligomeric, and fibrillar $\mathrm{A} \beta 42$ peptides on the proliferation and differentiation of adult neural stem cells from subventricular zone. J Neurochem. 2007 Jul;102(2):493-500.

39. Bernabeu-Zornoza A, Coronel R, Palmer C, Calero M, Martínez-Serrano A, Cano $E$, et al. A $\beta 42$ peptide promotes proliferation and gliogenesis in human neural stem cells. Mol Neurobiol. 2019 Jun;56(6):4023-36.

40. Wang Q, Tan Y, Zhang N, Xu Y, Wei W, She Y, et al. Dexmedetomidine inhibits activation of the MAPK pathway and protects PC12 and NG10815 cells from lidocaine-induced cytotoxicity at its maximum safe dose. Biomed Pharmacother. 2017 Jul;91:162-6.

41. Wang Q, She Y, Bi X, Zhao B, Ruan X, Tan Y. Dexmedetomidine Protects PC12 cells from lidocaine-induced cytotoxicity through downregulation of COL3A1 mediated by miR-let-7b. DNA Cell Biol. 2017 Jul;36(7):518-28.

42. Tan Y, Bi X, Wang Q, Li Y, Zhang N, Lao J, et al. Dexmedetomidine protects PC12 cells from lidocaine-induced cytotoxicity via downregulation of stathmin I. Drug Des Devel Ther. 2019 Jul 3;13:2067-79. 